\title{
Peculiarities of toponymic reflexes of Kazakhstan
}

\author{
Gulnara Boribayeva - Gulmira Madiyeva - Perizat Medetbekova - \\ Kudaibergen Mambetov - Janiya Ingamova
}

DOI: $10.18355 /$ XL.2018.11.01.29

\begin{abstract}
Toponyms are considered as the certain ethnocultural text bearing relevant information on the historical past of nations, on the borders of their resettlement, on the cultural, trade and geographical centers, etc. Thus, the problem of forming a particular - toponymic - worldview is an urgent task of modern linguistics due to its ethnocultural significance and integrative status as toponymic mapping of the world around represents one of the backbone methods of verbalizing the reality. It reflects the correlation between historical and social, language and ethnocultural aspects of the development of the people. The name serves not only as means of naming objects, but also contains information about the historical and cultural development of a society in which various social processes proceed. The research work is directed at observing the place names, realizing the process of interpretation of these names from the point of metalinguistic consciousness and determining the results. It is obvious that toponymic names are met when we are on the way or make a trip to a neighboring town, village, mountain, rivers, and lakes. Every traveler tries to define the meaning of the names they faced. The reason for that may be just curiosity or subject tries to define the properties of a geographical object, sometimes to learn the history of the object. The article aims to describe the language process that happens between the perception of the toponyms considered a geographical object by an ordinary native speaker and their interpretation and reflection.
\end{abstract}

Key words: reflection, linguistic consciousness, toponymic reflection, ordinary consciousness, ordinary metalinguistic consciousness

\section{Introduction}

As science is developing year by year, there are some changes in linguistics. New views, new information, new research methods in linguistics, and also the integration of language with other sciences and sub-fields in different ways caused new turn and new search in science.

One of its results is that native speaker focuses attention on his language, behavior, interpretation ability. It is an approach that has become an object of the research over the last thirty years.

In this sense the reflection of the relations of language and thinking, language and consciousness can be observed from the language behavior of a person or ability to express his opinion. It is a representation of researching a language from the anthropocentric viewpoint. Describing the initial element in learning the environment, perceiving, conceptualizing it, adding his opinion, giving his evaluation is a sign of realization of reflection in ordinary metalinguistic consciousness.

Reflex is a term peculiar in general to science. It became a research object in natural sciences (biology, neurology, physiology, mathematics, physics, chemistry, etc.) as well as in humanitarian sciences (philosophy, linguistics, sociology, etc.) in psychology that has the features peculiar to both sciences.

Anokhin (1945) and Kalashnikova (2006) state that reflex principle was first encountered in the works of R. Decartes. The information of who was the first to use the term was not confirmed because it was used in different fields. When P. Anokhin 
searched the word "reflex" as a key-word in the base of scientific journals in his research, it dated back to 1940 (Anokhin, 1945).

Reflex from the Latin reflexes means turns back, reflection. It is a response of an organism to the internal and external stimuli effect with the participation of the central nervous system. The phenomenon of reflex in linguistics can be considered as an influence of anything or phenomenon of human consciousness, its representation, and reflection in the language.

Reflection (in Latin reflexio - return) - the process of paying attention, feeling, thinking over himself, his consciousness, the results of activity of an individual. This indicates that "reflex is a general notion (reaction of an organism), and reflection is a relatively narrow notion (the term used related to only human)" (Shatova, 2015).

Psychological scientist S. Zhakypov also mentioned that reflection is a human phenomenon: "Reflection is directing human learning to himself, inner world, mental features, and condition" (Zhakypov, 2012).

"Thus, intelligence is the basis of reflection; the fact that human has intelligence means he has the reflexive ability of the mind," "each act of reflection is an act of judgment, understanding." (Kalashnikova, 2006).

The first notions of reflection according to influence as sense, consciousness, cognition, thinking, understanding and the second notions as verbalizing led to that reflection began to be studied in linguistics, in particular, cognitive linguistics, psycholinguistics, sociolinguistics.

So reflection is defined as a process, and linguistic consciousness, particularly ordinary metalinguistic consciousness is considered as a factor affecting this process.

I.A Baudouin de Courtenay mentioned in his research that there is "linguistic or linguist" type of thinking. He marks "Linguistic thinking" isn't just peculiar to linguists, but there is also special knowledge about language - national knowledge. Folk knowledge about language is shown as "... the linguistic feeling ability of people is not fictitious or subjective falseness conversely is a real, positive category (function) defining it by features and activities, approving from an objective point of view, proving to provide data" (Baudouin de Courtenay, 1963).

Taking into consideration the fact that there is national knowledge as well as scientific knowledge influenced increase of interest in the metalinguistic function of the simple native speaker. In Russian and national linguistics drawing attention to speech peculiarities of a speaker became widespread in the field of dialectology, in the course of collecting the materials from ordinary people. This was the background of the emergence of "Folk Linguistics."

We can say that a significant scientist Golev N.D. could form his own "school" at a definite level carrying out the research works. They were devoted to the identification of how the toponymic names are perceived by ordinary people; the names are analyzed by them, the observation of the ordinary metalinguistic awareness by these analyses and interpretations. According to N.D. Golev and L.M. Dmitriyeva (2008) if proper names form a system of human understanding of the world, from the beginning toponyms, emerged as a "marker" and assume "the representation of geographical reality in human consciousness."

Researching of toponyms is realized by using systematic principles as well as widely considered from "anthropocentric measures" (Pavlenko, Pavlenko, Stroganova, 2017). In this sense the authors of the article highlight the new paradigm of researching toponyms. So if toponyms have been studied on the basis "map, dictionary, name" beyond "a person" up to now, researching toponyms in anthropocentric aspect that provides studying the names directly in connection with the consciousness of a person, understanding them, representation in the consciousness, conveying in verbal

XLinguae, Volume 11, Issue 1, January 2018, ISSN 1337-8384, eISSN 2453-711X 
form introduces a new turn to science. The first researches here belong to "the ontological research system" and the last ones to "the mental research system": "Mental life of a system is defined by the concepts presented in semantic structure of names and represented in the toponymic contexts fixing the results of communicative activity of native speakers" (Golev \& Dmitriyeva, 2008).

N.D. Golev and L.M. Dmitriyeva (2008) noted that researching the toponymic materials in mental paradigm prioritizes over the issues as "pushing aside the problems concerning the history and etymology of names and the modern use of names and their role in people's relationship, perceiving name." The reason of that is explained with the topicality of defining the frequency of perception of toponymic names by ordinary people nowadays.

Such method gives a possibility in grouping the toponyms to classify not only according to the traditional "functions and types" but also in the aspect of "the geographical names perception in a definite linguistic group and their function in the consciousness of the individual."

A similar opinion was given by English researcher T.F. Thornton: "place names tell us something not only about the structure and content of the physical environment itself but also how people perceive, conceptualize, classify, and utilize that environment" (Thornton, 1997).

Anthropocentric research of place names was first reflected in the works of F. Boas (1887). He proposes to focus on toponymic names to study the culture of Indians in America (Boas, 1887). T.F. Thornton that studied such studies in America commented on the works of the researchers beginning with F. Boas to Keith Basso (Thornton, 1997).

In linguistics, the toponymic field considered as a part of onomastics, in particular, toponyms are being studied in ontological aspect among national scientists Zhanuzakov T., Rysbergen K., Abdirakhmanov A., and others. Studying toponyms as a geographical object, describing the historical periods and investigating the historical towns the Kazakhstani historians and archeologists, geographers had the main purpose to define the origin of place names and the reasons of naming them. Such an opinion is held by scientists Konkashpayev G., Koishybayev E., Baipakov K., Abdrakhmanov S., Gorbunov A., Saparov K. Such researchers as Kaidarov A., Pangereev A., Rysbergen K., Taspolatov B. studied toponyms in connection with folklore, on the basis of legends in the linguo-cognitive and ethnocultural aspect, considering the regional toponyms individually, from historical-linguistic, etymological, structural viewpoint.

The peculiarity of our research is in Kazakhstani names that are studied for the first time in the mental aspect. It is determined by the purpose and objectives.

The purpose of the research work is to define how the place names in Kazakhstan are reflected in folk consciousness. The following research methods are used to achieve the given purpose.

The hypotheses such as "the toponymic names formed in the consciousness of ordinary folk reflect the history of Kazakh people" and "in the course of explaining, analyzing the toponyms the social conditions (customs and traditions, mentality, principle) peculiar to the Kazakhs are defined" are offered in the research work.

The results of the research are expected to be enriched with theoretical statements about national consciousness, ordinary consciousness, linguistic consciousness, metalinguistic consciousness in Kazakh linguistics. In a practical aspect, the research results can be the basis for making the first steps in compiling explanatory, encyclopedic dictionaries, making an informative completely electronic filing base of Kazakhstan, improving the general functional literacy. 
What science studies an origin of geographical names? Each person can easily list hundreds of geographical objects connected with his place of living: villages, cities, rivers. When studying the past, their names can tell much. Try to find out why this area or the river is called so, but not differently. You will hear interesting stories. Scientists have established long ago that owing to the stability geographical names serve as the most ancient monuments allowing to get into depth of human history, culture, language. Many geographical names tell about the tribes and people created them. Sometimes using geographical names territorial borders of various nationalities can be defined, they also give interesting materials about features of the place, vegetation far back in the past or initial occupation of the population. Geographical names help to find foreign-language elements in this language. Thus, geographical names are valuable material for history, ethnography, archeology, botany.

There are different viewpoints on which field of science the area of science studying toponyms that are the objects of our research - toponymics belongs to. The famous Turkic scientist Budagov B.A. expresses his opinion about it: "As the toponymic develops, this ancient evidence is becoming clear. The toponymic is founded on three sciences - history, geography, and linguistics. It is precisely because of this fact that in the course of toponymic investigation one should be guided by these three sources. Otherwise, one-sidedness would yield no desirable results. Many errors found in toponymic investigations carried out in Azerbaijan occur through preference given to one source only. Toponymics without geography is spaceless, without linguistics is dumb, without history is rootless" (Budagov, 1997). E. Murzayev endorses his opinion: "toponymics is the boundary scientific discipline developing on a joint of three sciences: linguistics, history and geography - and using their L methods in an integrated way, pursues one aim - comprehensive study of geographical names" (Murzayev, 1974).

Toponymics is studied by three main sciences. Czech toponymist V. Smilauer (1958) and Russian researcher toponymist E. Murzayev (1974) remark that it is an independent science. The following requirements are given to the researchers who deal with toponyms as a research object: "the linguist, if he wants to work fruitfully in the field of toponymics, needs to know history and geography; the historian has to possess linguistic and geographical knowledge, and the geographer mustn't confine himself to a passive role, it is necessary to acquire data and methods of linguistic and historical sciences or in any case those of their sections which are most of all necessary for the toponymic analysis" (Murzayev, 1974).

In this respect, it is obvious that the researchers of each science use their methods in studying the names of geographical places. A. Reformatsky clarified this in his article: "geographical method is searching, geographer supplies and comments geographically; linguistic method -analysis and interpretation, linguist analyzes and explains linguistically; historical method - application, historian interprets and applies to history" (Reformatsky, 1964).

Detailed investigation of toponyms will result in the effectiveness of the work (Kaimuldinova et al., 2014). It is the main goal of every researcher studying toponyms. Nowadays, researching toponym in cognitive aspect, that is cognitive research is remarked to be in close relations with mentioned three sciences as well as other fields of science.

Our investigation consists of three phases. The first is drawing up a questionnaire, the second - the process of survey, the third - analyzing the results of the questionnaire. While drawing up the questionnaire five points to be taken into account in researching toponyms proposed by Berezovich E.L. (2009) were followed: 
It is necessary to take into consideration the regularities of object correlation of names (e.g., Almaty city, Shu river, etc.);

- It is necessary to consider semantic links in a paradigm of names of one object, i.e., semantics of parallel names of an object;

- While giving a semantic interpretation of names the relations within a semantic microsystem of toponyms can play an important role;

- It is necessary to consider the indications of linguistic consciousness of native speakers of toponymic system shown in the acts of a motivational reflection concerning place names;

- It is necessary to take an area of this or that model into account (Berezovich, 2009; Nakhanova, 2013).

The principles of choosing toponyms for the questionnaire are defined as follows: macrotoponyms and microtoponyms are considered, particularly we thought it right to choose hydronyms, oronyms, and oikonyms.

We scrutinized the names taken as an object of the research as a sphere of concepts by the work of Popova Z.D. and Sternin I.A. titled "Semantic and cognitive analysis of language." "The sphere of concepts of a person (the ordered set of the mental units reflecting the reality experienced by the subject) comprises information base of both consciousness, and thinking of the person" (Popova \& Sternin, 2007; Bugybayeva et al., 2015).

The aim of the questionnaire is to designate the toponymic reflection of the person of ordinary consciousness using the given names. The process of determination is as follows:

A respondent is offered a questionnaire form. The respondent chooses the questions about his hometown or fourteen regions that he wants to answer. All rules and conditions are explained to the respondents.

After the respondent answers the questions, each answer is examined individually and included in the list of names. Having at least twenty responses in each questionnaire form, we move to making a complex analysis. According to the complete statistics, 140 names were targeted, 20 respondents were responded on 14 questionnaires, there were ten toponyms in each questionnaire, and it means that if all questions concerning these names are answered, we will have 2800 explanations. However, if we take into account the fact that there are answers as "I do not know," "I have not heard" the number of the interpretations may be less than 2800. In case of considering the offerings given at the end of the questionnaire as "Give information about your place of birth," "information about extra toponyms," the amount of the answers may be more than we expected. We included only a part of the research into the article, i.e., we highlighted the questionnaire results obtained only on Almaty region among fourteen regions.

\section{Results and Discussion}

Ten names in Almaty region (4 oikonyms, 4 hydronyms, 2 oronyms or 5 macro- and 5 microtoponyms) were chosen for the questionnaire. The questionnaire was compiled according to the conditions of Berezovich E.L. (2009), and 20 respondents took part in it. They were aged 17-38 years, specialists in different spheres, residents of Almaty region and representatives of other regions living in Almaty.

The names were chosen for the questionnaire: Almaty, Yesik, Qhaskelen, Sarqhant, Medeu, Talghar, Qhapshaghay, Balqhash, Ile, Shelek. The extra toponyms added by the respondents (the names of place of their birth and additional information offered by them) - 24 (Zhongar Alatau, Zhelisai, Koilyk, Almaly, Karaboget, Kabanbai, Kara esek, Almerek, Yzynagash, Taldykorgan, Sarybulak, Zharkent, Shonzhy, Taraz, Malovodnaya, Ungirtas, Katonkaragai, Aktobe, Barsakelmes, Kalmakkyrylgan, Karasaz, Tuzdybastau, Targap, Qhazyghurt). The amount of toponyms that were not 
answered is 21: Yesik, Sarqhant, Balqhash (1), Medeu (2), Qhapshaghay (3), Talghar, Shelek (4), Ile(5). The respondents refused to give information about their birthplace 3. A number of the respondents who gave additional information (optional question) 6 . There were 3 answers as "don't know" the meaning, "don't know" any legends and data, "haven't heard" the meaning, of these there were 2 answers without interpretation. So it is possible to get the results of responses (see Table 1).

Table 1: Expected and obtained in a result responses

\begin{tabular}{|c|c|c|c|}
\hline & Total & Basic & $\begin{array}{l}\text { Addition } \\
\text { al }\end{array}$ \\
\hline $\begin{array}{lll}\text { Expected } & \text { number } & \text { of } \\
\text { responses } & & \end{array}$ & 240 & 200 & 40 \\
\hline Unanswered questions & -40 & -23 & -17 \\
\hline $\begin{array}{l}\text { Number of obtained } \\
\text { responses }\end{array}$ & 200 & 177 & 23 \\
\hline
\end{tabular}

As the questions aimed at receiving information on what the respondents think of the names, their origins, the responses of the respondents are considered according to the way of answering.

1. $\quad$ Expressing certainty/uncertainty while responding;

2. Giving answers in encyclopedic forms;

3. Describing by association;

4. $\quad$ Expressing positive opinion on a name;

5. Defining the characteristics of geographical object;

6. Diving information on if he knows/doesn't know the object, was/wasn't

there;

7. Eponymous identification;

8. $\quad$ Presence of the variants of legends in answers

9. Translation of the names and explaining;

10. Explaining by giving logical conclusion;

11. Comparing the name to a definite thing or phenomenon;

12. Fairy explanations and other peculiarities were noticed.

1. The first point was detected by meeting the word combinations as "know/don't know," "heard/ didn't hear," "was named/ was possibly named," "maybe was a place," "maybe was designated," "perhaps one...," "might be a place" etc. For instance, the answer of the respondents that are secure of their opinions about the name of Almaty is as follows: Alma ata degen kisige bailanysty qoiylghan [It was named related to a person Alma ata] (Almaty, AL 07); Alma aghashymen bailanysty. Alma baqshasy bolghandyqtan, aport sorty ko'p bolghandyqtan bul qalanyng atyn Almaty dep qoidy [It is connected to an apple tree. This city was named Almaty because there were an apple orchard and many sorts of apple] (Almaty, AL 17), etc. The samples of the explanations where you can meet doubtful usage concerning the origin of a name: Almaty oblysyna kirer zher bolghan song Yesik degen atau berildi dep oilaimyn [I think it was named as Yesik (means door) because it is the beginning of Almaty region territory] (Yesik, AL 13); Mening oiymsha, barlyghyna belgili "Yesik qorghany" tabylghandyqtan solai ataluy kerek [In my opinion, it must be named so because the widely known "Yesik burial mound" was found there] (Yesik,

XLinguae, Volume 11, Issue 1, January 2018, ISSN 1337-8384, eISSN 2453-711X 
$A L 05)$ and etc.

2. The next point - giving answers in encyclopedic forms - is present in most of the responses. For example, Qarluqtar zamanynda 7-9 gh. Zhetisuda salynghan qonystardyng biri 1861 zh. alghashynda Lyubovnyi bolsa, 1901 zh. Qhaskelen atalghan [in the period of Qarluqhs 7-9 centuries, if one of the landings built in Zhetisu was first Luybovnyi in 1861, in 1901 it was named as Qhaskelen] (Qhaskelen, AL 8); Alataudyng soltu'stik betkeyinen bastau alady. 70 arnasy bar. Kegen, Shelek auyl sharuashylyqtary egin alqaptaryna paidalanady [It begins from the northern slope of Alatau. It has 70 channels. Agricultural sectors like Kegen, Shelek use them for farming agriculture] (Shelek, AL 14);

3. Only a few associative descriptions in comparison to other answers are met: Almaly meken [Appleland] (Almaty, AL 05); Zhalpy "Yesik" degen sozdi yestigende birden oigha "Altyn adam" keledi [In general when you hear the word "Yesik" "Golden Man" comes to mind at once] (Yesik, AL 15); "Qas qaraighan sa't". "Tynyshtyq." "Ymyrt kez" degen maghynada dep oylaymyn [I think in the meaning of "moment when it becomes dark." "Silence." "Twilight"] (Qhaskelen, AL 01); Bul audannyng yeski atauy biluimshe Talkhiz atalghan. Al bul ataudy yestigende, qalyng aghash, nu orman, qysta qalyng qar zhauyp zhatqan tau yelesteyd [The former name of this region was, as far as I know, Talkhiz. When I hear this name, I imagine thick trees, thick forest, the mountain where it is snowing in the winter] (Talghar, AL 03), etc.

4. Among the responses, there were the cases of expressing a positive opinion about the names: Qosymsha Qhazyghurt auyly turaly ma'limet bergim keledi. Qhazyghurt degen taudyng o'zi o'zime zhagymdy yestiledi. Diniy nanym-senim boyynsha kezinde Nukh payghambardyng kemesi toqtaghan zher deydi. Kezinde Nukh payghambar topan sudan adamzatty qorghap qalghan deydi. Zhalpy tirshilik, adamzat sol zherden taraghan desedi [In addition I would like to give information about Qhazyghurt. The name Qhazyghurt is nice to hear from me. According to the religious beliefs, it was a place where the Ark of Nukh the Prophet stopped. They say that Nukh the Prophet in olden times saved the humanity from the flood. They say that the whole life, humanity began from that very place] (Almaty, AL 14).

5. Describing the nature of the geographical object was realized in two ways: the first, by metaphorical word usages, the second, describing in areal aspect. In the course of interpreting the name using metaphorical way of expressing in comparison to describing in areal aspect is met more often. For instance, Almaty oblysynda zheri qunarly tabighaty taza zherde ornalasqan. Ainalasyn a'sem taular qorshap tur. Almaty dep atalu sebebi, osy zherde alma aghashtarynyng o'te ko'ptiginen zhane olardyng ta'ttiligimen, sapalylyghymen tanylghandyqtan [It is located in a fertile land with pure nature in Almaty region. It is surrounded by beautiful mountains. The reason why it is named as Almaty is connected with the fact that there are many apple trees and they are famous for their quality, sweetness] (Almaty, AL 18); etc.

Area description is used in the following responses: Almaty oblysy Engbekshiqazaq audanynyng ortalyghy. Qalanyng ornyn adamdar o'te erteden mekendegen. Soltustik zhaghynda saq ma'denietining ko'rnekti eskertkishi - Yesik obasy ornalasqan [Almaty region is the center of Engbekshikazakh district. People inhabited the place of the city from ancient times. In the northern part there is a famous monument of the culture of Saks - Issyk mound] (Yesik, AL 08); and so on. There is also the mixed type of both of these directions: Sarqhant Taldyqorghan zhaqqa qarasty meken. Zhazy zhaidary. Zher koinauynan betonit keni o'ndiriledi [Sarqhant is a locality as a part of Taldykorgan. Its summer is so pleasant. Bentonite is produced here] (Sarqhant, AL 14); etc.

6. Giving information about that if he knows/ doesn't know the object, he was/wasn't there - has a particular place among the answers. Because the respondent justifies his answer showing is he knows the name of the object or not (or if he was there or not). The answers proving that "he knows" were mentioned above, that is why we will not describe them. For example, Bul qalada bolghanmyn, degenmen maghynasyna ungilip 
ko'rmeppin (o'kinishke orai). Endi anyqtap koru kerek [I was in this city, but never paid attention to the meaning (unfortunately). Now I have to define it] (Yesik, AL 01); Bul ataudyng koiylu sebebimen tanys emespin. Elektr su stantsiyasy bar ekenin zha'ne bo'gende balyq turleri baryn, bo'gen suymen ko'rshiles eldi-mekender baqsha daqyldaryn egetini turaly ghana aqparatpen tanyspyn [I am not introduced with the reason of naming it so. I just know information about that there are a hydro power plant and types of fish in the water basin, that the neighboring localities situated near the water basin plant garden crops] (Qhapshaghay, AL 12); Qhapshaghay su qoimasynyng bary barlyghymyzgha belgili. Ko'pshilik zhurt demalys orny, shomylu dep elestetedi [We all know that there is Qhapshaghay water basin. Most of the people imagine it as a place for rest and swimming] (Qhapshaghay, AL 14);

7. Eponymous identification is likening to the names of a person, hero, character, character of a legend, scientists. E.g. Mening oiymsha esik batyrdyng atyna qoiylghan [To my mind it was named after Yesik hero] (Yesik, AL 02); Sol zherde engbek etken adamnyng qurmetine qoiylghan [It was named in honour of a person who worked there] (Sarqhant, AL 10); Burynyraqta bul zherde zhalfgyz qhana kisining uii bolghan zha'ne ol kisisning aty-Medeu [Earlier there was a house of only one man here, and this man's name was Medeu] (Medeu, AL 01); Qhabysh aghai degen sozden shyqqan shyghar [It comes possibly from the words Qhabysh agai (means brother Qhabysh)] (Qhapshaghay, AL 07);

There are a lot of eponymous identifications related to the name Qhaskelen; some respondents write he was a hero, some - khan, ones - khuntaishy, while others convince that he was a representative of Kalmyk, some - Dzungar, ones - Mongol. That is there is an idea that it appeared from the Kazakh-Kalmyk, Kazakh-Mongol, Kazakh-Dzungar relations. For instance: Monggholdardyng ataqty batyry Qhaskelen [Famous batyr of Mongols - Qhaskelen] (Qhaskelen, AL 02); Ol zhongghar batyrdyng aty [This is a name of Dzungar batyr] (Qhaskelen, AL 10); Zhongghar shaiqasynda Nauryzbai batyr o'ltirgen zhongghar qontaishysy [The name of Dzungar khuntaishy killed by Nauryzbai batyr in Dzungar battle] (Qhaskelen, AL 09); Qhaskelen qalasynyng atauy zhonghar khanynyng esimine bailanysty qoiylghan [The name of Qhaskelen town was given in connection with the name of Dzungar khan] (Qhaskelen, AL 11);

As the name Qhaskelen eponymous identification related to the lake Balkhash are used in various versions, one is likening to a girl, the next one to a rich man, and another one to an old man: Anghyz boiynsha, Balqiya degen qyz. [According to the legend there was a girl named Balqiya] (Balqhash, AL 02); Anghyz: Balqhash degen bai bolady [Legend: There was a rich man with the name Balqhash] (Balqhash, AL 08); Onyng aqyldy, sulu, Baliya degen qyzy bolypty, ony erkeletip Balqhash dep ataghan [He had a smart, beautiful daughter named Balkiya, he called her affectionately Balqhash] (Balqhash, AL 09); Ertede Balyqshy ata dep ataluy mumkin [In the past it was probably called as Balykshy ata] (Balqhash, AL 20); These names are spread in different versions due to the legends among people, this will be reviewed at the next point.

8. Presence of the variants of legends in answers. There are few names in the answers to which the legends are given; they are about river Ile and lake Balqhash. As the legends are handed down the plot, characters and other elements are met in different versions. Most of the legends are about lake Balqhash and river Ile. The last idea of all of them is that it appeared from the tears and someone died jumping into this water, and it was the reason for giving his name to it (Saparov, 2003). We can say that these conclusions are motives peculiar to most of the hydronyms in Kazakhstan. As one of the variants, the name Balqhash is given as a name of a girl but sometimes of a rich man, and such comparison is connected with the name of river Ile that is believed to be originated from the name of a girl or sometimes of a young man.

XLinguae, Volume 11, Issue 1, January 2018, ISSN 1337-8384, eISSN 2453-711X 
9. Translation of names and giving explanation are mostly given in relation to the toponyms the meaning of which is not clear. There were some answers that couldn't give interpretation of the names and that's why they gave information that the name was borrowed from another language: Mumkin qazaqtyng emes, o'zge ulttyng tilinde boluy kerek [It must be in the language of another nation but not in Kazakh] (Qhapshaghay, AL 01); Kirme so'z dep oilaimyn [I think it is a loanword] (Qhapshaghay, $A L$ 03). Certainly here the geographical location of the name was taken into account, the conclusions were made based on the neighbouring countries and historical stories. For example, Mening oiymsha, bul mongghol tilinen engen so'z. Sebebi, eki el arasynda turli qarym-qatynastarynyng bolghany belgili [In my opinion this is a word borrowed from the Mongolian language. Because it is known that there were different relations between two countries] (Qhaskelen, AL 03); "Qashqa" zha'ne "Yeleng" so'zderinen shyqqan. Qashqa so'zi - tasqyn, aghysynan bo'lingen tasyghan su degen maghynada aitylghan [It was originated from the words "Qashqa" and "yeleng". The word Kashka means stream, overflown water] (Qhaskelen, AL 06); and so on.

10. Explaining by giving logical conclusion. Mening oiymsha, bul yeski Zhetisu zherindegi qala bolghandyqtan, sauda-sattyqtyng qaqpasynyng biri bolyp, Yssyk nemese Yesik atauyn alghan [To my mind as it was a town on the territory of ancient Zhetisu, it got its name Issyk or Yesik being one of the gates of trade] (Yesik, AL 03); Mening oiymsha Sarqhant atauy "sary kent" tirkesinen shyqqan. Sebebi bul audanda iri-iri ka'siporyndar, energetika zhuiesi ornalasqan. Aitylu ynghaiyna qarai Sarqhant bolyp [I think the name Sarqhant came from the word combination "sary kent» (yellow small town). Because there are large industries, energy systems. It was changed to Sarqhant for pronouncing it easily] (Sarqhant, AL 12); etc.

11. Comparing the name to a definite thing or phenomenon: "Qasty kelin" degen so'zge uqsaidy [It is like the word "Qasty kelin" (thick eyebrowed daughter-in-law)] (Qhaskelen, AL 20); Samarqand atauyna uqsas eken, mumkin attas bolghan shyghar [it is similar to the name Samarkand, maybe they were of the same name] (Sarqhant, AL 06); Sarqhylma degen ataugha uksas dep oilaimyn [I think it is similar to the name Sarkylma] (Sarqhant, AL 13); Sarqhan yaghni sarqylghan degennen shyqqan shyghar [Sarqhan possibly came from sarkylgan (extinct, exausted)] (Sarqhant, $A L$ 20); Sary qant shyghatyn zher [Place where yellow sugar is produced] (Sarqhant, Al 19); Medeu "demeu” degen so'zge uqsaidy, bayaghyda zhaudan qashqanda adamdargha pana, demeu bolghan tau shyghar [Medeu is similar to the word "demeu" (maintenance), earlier maybe it was a mountain that was a hiding-place, maintenance for the people that had run away from enemies] (Medeu, AL 07) and so on.

12. Responses with fairy explanations and other peculiarities: Yeski dunie men zhanga zaman arasyndaghy yesik dep ataghan degen oidamyn. Sebebi, ol qaladan ko'ptegen yeskertkishter, yeski qalalar bar, sonymen birge "Altyn adam" da tabylghan [I think it was named as a door between ancient and modern world. Because a lot of monuments, ancient towns were found in this town, along with that "Golden Man" was also found] (Yesik, AL 06); Qalanyng ainalasyn tau qorshap turghan bir a'sem ko'rinis. Alystan ma'n berip qarasaq, bir keremet ko'rinis ol - ghazhaiypqa aparar zhol "yesik" siyaqty [The view is spectacular as the town is surrounded by mountains. If you look at it from a distance, you will see a great scenery - "door" leading to miracle] (Yesik, AL 18); Bir ataqty kisining qasynyng qalyngdyghyna bailanysty qoiylghan shyghar [The name was possibly given because of the thickness of eyebrows of a famous person] (Qhaskelen, AL 16); Eng alghash shelek oilap tabylghan zher boluy mumkin [It may be a place where the first bucket was invented] (Shelek, AL 20).

It is possible to study all of these given responses, but their other features will be reviewed in future research. 


\section{Conclusion}

When a person explains the meaning, he consciously or subconsciously uses the most optimal, from his point of view, means of cogitative action. A.N. Rostova tells about the four-dimensional orientation of ordinary metalinguistic consciousness - the native speaker, explaining a word meaning, appeals to "the world of things," "the world of words," "the world of functional situations" and "the personal, associative world." The first three types of the relations are caused by an object of interpretation (the language device: connection of "word - designated reality," "word - other words," "word - functioning"), the fourth - a subject (features of human memory and process of association). This four-dimensional orientation of metalinguistic consciousness defines the choice of strategy of interpretation of meanings. The strategy of interpretation of meaning is understood as "a natural way of cogitative action which is resulted in judgment and interpretation of meanings" (Rostova, 2009; Superanskaya, 2009).

When a respondent is giving his interpretation on any toponym, first of all, he defines if the name is familiar/unfamiliar, some of them analyze that they were/ weren't in that geographical place, then they rely on the basic information they know about that toponym. Is there is no connection between the respondent and toponymic name then the respondent pays attention to the pronunciation of that name, i.e., external shape, its similarity to another word, thing, phenomenon, in other words, toponym picks up necessary information from the metalinguistic consciousness of the respondent?

Summing up the research results reviewed above it is possible to have a general representation of toponym. This shows that the work has high potential.

\section{Bibliographic references}

ANOKHIN, P. 1945. Ot Decarta do Pavlova: Trista let teorii refleksa [From Descartes to Pavlov: Three hundred years of reflex theory]. Moscow. $112 \mathrm{p}$.

BAUDOUIN DE COURTENAY, I.A. 1963. Izbrannye trudy po obschemu yazykoznaniyu: v 2 tomah [Selected Works on General Linguistics: in 2 volumes]. Moscow. 384 p.

BEREZOVICH, E.L. 2009. Russkaya toponimiya v etnolingvisticheskom aspekte: Prostranstvo i chelovek [Russian toponymy in the ethnolinguistic aspect: space and people]. Moscow. Publishing house "LIBROKOM". 328 p. ISBN: 978-5-397-052788.

BOAS, F. 1887. The Study of Geography. In: Science. Volume 9. Issue 210. Pp. 137141. ISSN: 00368075.

BUDAGOV, B.A. 1997. Turetskiye Toponimy Evrazii [Turkic Toponyms of Eurasia]. Baku, Publishing house "Elm". 174 p. ISBN: 5-8066-0757-7.

BUGYBAYEVA, Zh. B. - ZHADRAYEVA - L. U., KABULOVA, A. R. SHEKERBEKOVA, S. T. - BOGATOV, T. A. - BERKINBAYEVA, G. O. 2015. Ethnographic Development of Kazakh Toponymy. In: Mediterranean Journal of Social Sciences. Volume 6. Issue 4. Pp. 462-466. ISSN: 20392117.

GOLEV, N.D. - DMITRIYEVA, L.M. 2008. Edinstvo ontologicheskogo i mental'nogo bytiya toponimicheskoi sistemy (k problematike kognitivnoi toponimiki) [The unity of the ontological and mental existence of the toponymic system (to the problems of cognitive toponymy)]. In: Voprosy onomastiki. Volume 14. Issue 5. pp. 5-17. ISSN 1994-2400.

KAIMULDINOVA, K. - ABDIMANAPOV, B. - BERDYGULOVA, G. JANGELDINA, D. - ABILMAZHINOVA, S. 2014. Toponymic Evidence of Change in the Water Regime of the Lakes in Kazakhstan. In: World Applied Sciences Journal. Volume 30. Issue 2. Pp. 161-166. ISSN: 18184952.

KALASHNIKOVA, N.A. 2006. Refleksiya kak printsip filosofskogo myshleniya

XLinguae, Volume 11, Issue 1, January 2018, ISSN 1337-8384, eISSN 2453-711X 
[Reflection as a principle of philosophical thinking]. Abstract of Diss. For Dr. Philosophical Sciences. Volgograd. 28 p.

MURZAYEV, E.M. 1974. Ocherki toponimiki [Essays on toponymy]. Moscow. Publishing house "Mysl"'. $382 \mathrm{p}$.

NAKHANOVA, L.A. 2013. Lexical-Semantic Analysis of the Ancient Turkic Place Names. In: World Applied Sciences Journal. Volume 26. Issue 4. Pp. 475-483. ISSN: 18184952.

PAVLENKO, A. - PAVLENKO, G. - STROGANOVA, O. 2017. Placenames of Scottish origins in Russia (a toponymic index and description). In: Xlinguae Journal. Volume 10. Issue 3. Pp. 150-162. ISSN: 13378384.

POPOVA, Z.D. - STERNIN, I.A. 2007. Semantiko-kognitivnyi analiz yazyka: monografiya [Semantic-cognitive analysis of language: monograph]. Voronezh. Publishing house "Istoki". $250 \mathrm{p}$.

REFORMATSKY, A.A. 1964. Toponomastika kak lingvisticheskii fakt [Topomastics as a linguistic fact]. Moscow. Publishing house "Nauka". 34 p.

ROSTOVA, A.N. 2009. Obydennaya semantizaciya slov [Ordinary semantisation of words]. In: Obydennoe metayazykovoe soznanie: ontologicheskie i gnoseologicheskie aspekty. Kollektivnaya monografiya [Ordinary metalanguage consciousness: ontological and epistemological aspects. Collective monograph]. Kemerovo-Barnaul. Publishing house of Altai University. 202 p.

SAPAROV, A. 2003. The alteration of place names and construction of national identity in Soviet Armenia. In: Cahiers du monde russe. Volume 44. Issue 1. Pp. 179198. ISSN: 12526576.

SHATOVA, N. 2015. Svyaz' terminov "refleks" i "refleksia" dlya psichologopedagogicheskih issledovanii: leksicheskii i logicheskii aspekty [The connection between the terms "reflex" and "reflection" for psychological and pedagogical research: lexical and logical aspects]. In: Izveitiya Saratovskogo gosudarstvennogo universiteta [Proceedings of the Saratov State University]. Volume 15. Issue 1. Pp. 111-118. ISSN: 187177115.

SMILAUER, V. 1958. Metoda «malych typu» v toponomastice. Sbornic slavistickych praci venovanych. IV Mezinarodnimi Sjezdu slavistu v Moskwe ["Malych type" method in toponomastics. Proceedings of Slavonic works devoted to. IV International Congress of the Slavic Congress in Moscow]. Praga.

SUPERANSKAYA, A.V. 2009. Obschaya teoriya imeni sobstvennogo [General theory of the proper name]. Moscow. Publishing house "LKI". 368 p. ISBN: 978-5397-00138-0.

THORNTON, T.F. 1997. Anthropological Studies of Native American Place Naming. In: American Indian Quarterly. Volume 21. Issue 2. pp. 209-228. ISSN: 0095182X. ZHAKYPOV, S.M. 2012. Zhalpy psichologiya negizderi [The basis of psychology Zhalpi]. Almaty. Publishing house "Alla prima". 203 p.

\section{Words: 6190}

Characters: 41228 (22,90 standard pages)

Gulnara Abdikassimovna Boribayeva, PhD Candidate,

Department of General Linguistics and European languages

Al-Farabi Kazakh National University

Al-Farabi Ave.,71

050034 Almaty

Kazakhstan

kasymgulnar@gmail.com

Head of Chair Gulmira Bajanzhanovna Madiyeva, D.Sc. in Philology 
Department of General Linguistics and European languages Al-Farabi Kazakh National University

Al-Farabi Ave.,71

050034 Almaty

Kazakhstan

Gbmadiyeva.kz@gmail.com

Perizat Tyktibaevna Medetbekova, Cand.Sc. (Philology)

Department of General Linguistics and World Languages

Al-Farabi Kazakh National University

Al-Farabi Ave.,71

050034 Almaty

Kazakhstan

medet_73@mail.ru

Kudaibergen Smaylovich Mambetov, Cand.Sc. (Philology)

Department of Turkic Studies

Akhmet Yassawi International Kazakh-Turkish University

B. Sattarhanov Str., 29

X42F6X7 Turkestan

Kazakhstan

mmanshuk@mail.ru

Janiya Gazimovna Ingamova

Atyrau State University named after Kh. Dosmukhamedov

Department of Translation and Foreign Languages

Studencheskiy Ave., 212

060001 Atyrau

Kazakhstan

ms.ingamova@mail.ru 